\title{
The effect of ginseng supplementation on strength development in response to resistance exercise training
}

\author{
Angelheart Joy Maynard Rattu
}

\begin{abstract}
Abstrak
Pengaruh pemberian ginseng terhadap kekuatan otot telah banyak kali diperdebatkan tetapi pengaruh tersebut sebagian besar masih belum diketahui dengan pasti. Oleh karena itu penelitian ini dirancang untuk mengetahui pengaruh pemberian ginseng selama program latihan beban terhadap kekuatan otot. Tiga puluh tiga orang coba yang sehat dibagi dalam 2 kelompok masing-masing (i) program latihan beban dengan asupan ginseng (GIN); (ii) program latihan beban tanpa asupan ginseng (plasebo, PLA). Kekuatan otot diukur menurut protokol latihan beban maksimal dan ini dilakukan sebelum dan sesudah program latihan beban 2 kali seminggu selama 8 minggu. Pria memiliki kekuatan otot yang lebih besar dibanding wanita, baik sebelum maupun sesudah program latihan beban. Persentase pertambahan kekuatan otot masing-masing 18,1\% pada pria dan 17,9\% pada wanita, tetapi secara statistika perbedaan ini tidak bermakna. Kekuatan otot meningkat secara bermakna sesudah program latihan beban tetapi tidak terdapat perbedaan bermakna antara kelompok GIN dan kelompok PLA. Rata-rata pertambahan persentase kekuatan otot adalah $14 \%$ pada kelompok PLA dan $20 \%$ pada kelompok GIN namun perbedaan ini secara statistika tidak bermakna. Oleh karena itu disimpulkan bahwa program latihan beban sama-sama efektif dalam meningkatkan kekuatan otot pada pria dan wanita, akan tetapi asupan ginseng tidakmemberikan pengaruh yang berarti dalam pertambahan kekuatan otot.
\end{abstract}

\begin{abstract}
The influence of ginseng supplementation on muscular strength is much debated but largely unknown. Therefore the present study was designed to explore the effectiveness of ginseng ingestion on strength development in response to resistance exercise training. Thirty three normal healthy subjects were divided into 2 groups (i) resistance exercise with ginseng supplementation (GIN); (ii) resistance exercise without ginseng supplementation (placebo, PLA). Strength indices were determined using maximal resistance exercise (MRE) protocol before and after a weight training program twice a week for eight weeks. Males generated significantly greater muscular strength compared with females before and after the conditioning program. The average percentage gain in muscular strength was $18.1 \%$ for males and $17.9 \%$ for females, this differences was not statistically significant. Muscular strength increased significantly after the conditioning program with no statistically significant differences being observed between GIN and PLA group. The average percentage gain in muscular strength was $14 \%$ for the PLA group and $20 \%$ for the GIN group, these differences were not statistically significant. It is therefore concluded that resistance exercise training was equally effective in increasing whole body muscular strength in males and females. However, ginseng supplementation had no added effect on muscular strength gain.
\end{abstract}

Keywords : ginseng, resistance training, muscle strength

Panax ginseng is currently one of the most widely used plant products in Oriental medicine and has been used in the treatment of several diseases such as nervous disorders, amnesia, and diabetes mellitus. ${ }^{1,2}$ Ginseng extracts have also been administered to increase occupational efficiency involving physical labor as well as increase physical performance. Most of the pharmacological studies regarding the effect of ginseng on physical performance have been conducted in animals.

Department of Physiology, Faculty of Medicine, Sam Ratulangi University, Manado, North Sulawesi, Indonesia
For example, Popov and Goldwald ${ }^{3}$ examined the effect of placebo and ginseng extract on endurance performance (swimming) in mice. Results showed that endurance time improved $35 \%$ on the placebo trial, and $59 \%$ on the ginseng condition.

The physiological effects of ginseng on physical performance in humans have been reported infrequently. For example, the effect of two different doses of ginseng on physical performance were examined by Kirchdorfer. ${ }^{4}$ The result demonstrated a significant increased in acrobic capacity with no significant difference between the two doses. McNaughton et $\mathrm{al}^{5}$ 
examined the acute effects of two different types of ginseng supplementation (Russian and Chinese) on strength development in males. Pectoral and quadriceps strength measures were significantly greater only in the group who had ingested the Chinese ginseng compared with controls.

Resistance exercise is becoming widely used and accepted, not only in sports training, but also in recreational and health related exercise as well as occupationally related training. Highly specialized and sophisticated resistance exercise programs are part of most athletic training programs today. The inclusion of resistance exercise equipment for recreational lifters in various types of physical and cardiac rehabilitation program is widespread. ${ }^{6}$ Although the physiological effects of resistance exercise on muscular strength and body composition have been extensively studied and widely report, ${ }^{7-10}$ no evidence is available in the literature regarding the effect of resistance exercise training with and without ginseng supplementation on strength development in young adults. Therefore the present study was designed to examine the effects of ginseng administration in combination with resistance exercise on strength development in males and females.

\section{MATERIALS AND METHODS}

\section{Subjects}

Thirty-three (21 male and 12 female, $21.0 \pm 1.5$ years) normal healthy subjects volunteered to participate in this study. Subjects had not previously participated in an organized weight-training program, but were involved in other sports activities both before and during the duration of the study. Experiments were carried out on males and females in an attempt to compare the physical responses in both sexes. Ethical approval was obtained from the University Ethics Committee and an informed consent was procured from each subject before participation.

The subjects were divided into two experimental groups (i) resistance exercise with ginseng supplementation (GIN, N=14, 7 males, 7 females; (ii) resistance exercise without ginseng supplementation (PLA, N=19, 14 males, 5 females). The randomization between the two experimental groups was balanced by a rough estimation of body size, age and training status.

When subjects reported to the laboratory for testing, body mass and percentage body fat were determined. Percentage body fat was estimated from skinfold measurements as described by Durnin and Womersley. ${ }^{11}$

\section{Maximal resistance exercise testing before and after the training program}

After familiarization, the subjects were scheduled into morning pre-conditioning testing sessions. Subjects reported to the laboratory in pairs and were fed a standardized breakfast $(50 \mathrm{~g}$ cereal and $100 \mathrm{ml}$ of skimmed milk; energy $946 \mathrm{~kJ}$, carbohydrate $52 \mathrm{~g}$, protein $3.6 \mathrm{~g}$, and fat $0.4 \mathrm{~g}$ ). Maximal resistance exercise testing was conducted at the same time of day (08:00-12:00 hours) in an ambient temperature of $24 \pm 2^{\circ} \mathrm{C}$ and relative humidity of $55 \pm 5 \%$.

The maximal resistance exercise test consisted of the completion of three sets of seven different exercises using resistance (weight) corresponding to 15 repetition maximum (15 RM). The 15-RM strength was determined for each exercise to obtain measures of maximal resistance exercise volume for the upper and lower body parts. The $15 \mathrm{RM}$ was defined as the maximal weight that could be lifted 15 times through the full range of motion employing the correct techniques. Resistance exercises performed were bench press, leg press, latissimus pull down, prone leg curl, shoulder press, leg extension and standing biceps curl. Rest periods interspaced exercises $(30 \mathrm{~s})$ and sets (120 $\mathrm{s})$. Exercise volume $(\mathrm{kg})$ was calculated by multiplying the number of sets by the number of repetitions times the weight lifted per repetition. ${ }^{12}$

\section{Resistance exercise conditioning program}

All subjects in the two experimental groups exercised twice weekly for eight weeks. The sequence of exercises in the first profile was bench press, leg press, latissimus pull down, prone leg curl, shoulder press, leg extension, and standing biceps curl. In the second profile the sequence of exercises was shoulder press, leg press, latissimus pull down, leg extension, bench press, prone leg curl and standing biceps curl. Both these sequences of exercise were arranged so that the multi-joint exercises using the largest muscle mass and requiring the greatest effort came first in the order. Maximal strengths of major muscle groups for upper and lower body parts were determined in both experimental groups before and after the training period using 15 RM. Subjects were continually encouraged to push themselves and increase both repetitions and the weight lifted. When subjects improved in strength, weights were progressively increased to elicit $15 \mathrm{RM}$ for each exercise. 


\section{Ginseng and placebo tablets administration proce- dures}

Subjects were randomly assigned to receive either the ginseng supplement or placebo. Ginseng $(600 \mathrm{mg}$ Panax ginseng, Red Korean ginseng) or placebo (sugar-free) tablets were ingested daily on weekdays between 16.30 and 19:00 hours. Tablets were kept in coded bottles and administered in a double blind fashion.

\section{Statistical analysis}

The statistical analysis of the data were carried out using analysis of variance (ANOVA) with repeated measurements. The dependent variables body mass, percentage body fat, and strength indices was entered into two $2 \times 2$ ANOVA models to detect differences between ginseng-placebo and pre-post conditioning tests and between male-female and pre-post conditioning tests, respectively. A level of $\mathrm{p}<0.05$ was chosen to indicate significance.

\section{RESULTS}

Body mass and estimated percentage body fat before and after the conditioning program.

Table 1. Body mass and estimated percentage body fat in males $(\mathrm{N}=21)$ and females $(\mathrm{N}=12)$ before $(\mathrm{A})$ and after (B) conditioning.

\begin{tabular}{clll}
\hline & & \multicolumn{1}{c}{$\mathrm{A}$} & $\mathrm{B}$ \\
\hline $\begin{array}{c}\text { Weight } \\
(\mathrm{kg})\end{array}$ & Males & $72.0 \pm 1.5^{*}$ & $72.3 \pm 1.7^{*}$ \\
Fomales & $62.0 \pm 2.0$ & $60.7 \pm 1.4$ \\
$(\%)$ & Males & $15.4 \pm 1.1^{+}$ & $16.2 \pm 1.0^{+}$ \\
\hline
\end{tabular}

* significantly $(\mathrm{P}<0.05)$ higher than that observed in females.

${ }^{+}$significantly $(P<0.05)$ lower than that observed in females.

Table 1 shows the mean values of body mass and estimated percentage body fat in males and females before and after the conditioning program. Body mass was significantly $(p<0.05)$ higher in males compared with that observed in females both before and after the conditioning program. Resistance exercise training induced no significant change in body mass in males or females.

Percentage body fat was significantly $(p<0.05)$ higher in females compared with that found in males. This was found both before and after conditioning. The statistical comparison of the mean values of the percentage body fat before and after conditioning also revealed no significant differences in either males and females.

Table 2. Body mass and estimated percentage body fat for placebo $(\mathrm{N}=19)$ and ginseng $(\mathrm{N}=14)$ before $(\mathrm{A})$ and after (B) conditioning.

\begin{tabular}{clcc}
\hline & & A & B \\
\hline Weight & Placebo & $69.4 \pm 2.3$ & $68.5 \pm 2.3$ \\
$(\mathrm{~kg})$ & Ginseng & $66.5 \pm 2.7$ & $67.2 \pm 3.0$ \\
Body fat & Placebo & $21.2 \pm 2.2$ & $22.2 \pm 2.1$ \\
$(\%)$ & Ginseng & $17.9 \pm 2.0$ & $20.2 \pm 2.3$ \\
\hline
\end{tabular}

The results of body mass and estimated percentage body fat for placebo and ginseng groups before and after the conditioning program are presented in Table 2 . The mean values of body mass did not vary significantly between placebo and ginseng groups either before or after conditioning. Likewise, no statistically significant change in body mass was observed in response to the conditioning program in any group.

No statistically significant difference in the percentage body fat was observed between placebo and ginseng groups before the conditioning program. Resistance exercise training induced no statistically significant change in percentage body fat in any of the groups studied.

\section{Strength development in response to the resis-} tance exercise conditioning program.

Muscular strength, expressed as total exercise volume, in male and female groups before and after the conditioning program is presented in Figure 1. Males generated significantly $(p<0.001)$ greater exercise volume in compared with females before and after the conditioning program. The average percentage gain in term of total exercise volume was $18.1 \%$ for males and $17.9 \%$ for females, this differences was not statistically significant $(\mathrm{p}=0.70)$.

Total exercise volumes in placebo and ginseng groups before and after the conditioning program are graphically depicted in Figure 2. Muscular strength expressed as total exercise volume, increased significantly $(\mathrm{p}<0.05)$ after the conditioning program with no statistically significant differences being observed between groups. The average percentage gain in terms of total exercise volume was $14 \%$ for the 
placebo group and $20 \%$ for the ginseng group, these differences were not statistically significant $(p=0.90)$.

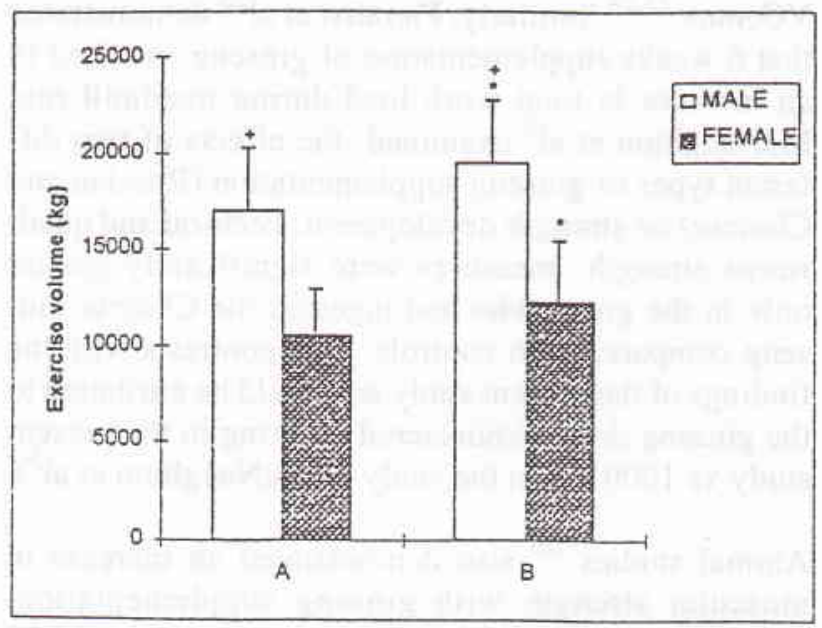

Figure 1. Exercise volume (mean $\pm S D)$ in male $(N=21)$ and female $(N=12)$ groups before $(A)$ and after $(B)$ conditioning. ${ }^{+}$significantly higher $(p<0.001)$ mean value than that $o b$ served in females. *significantly higher $(p<0.05)$ than that observed before conditioning.

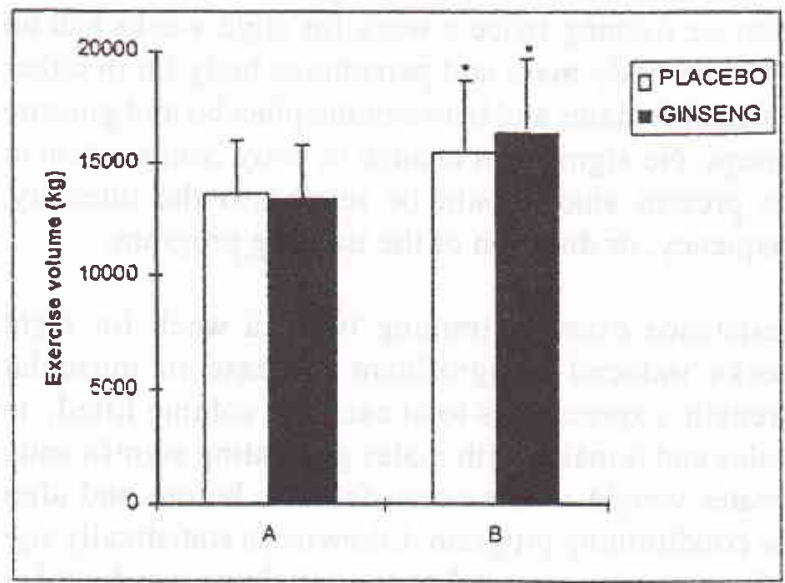

Figure 2. Exercise volume (mean $\pm S D)$ in placebo $(N=19)$ and ginseng ( $N=14$ ) groups before $(A)$ and after $(B)$ conditioning. *significantly higher $(p<0.05)$ mean value than that observed before conditioning.

\section{DISCUSSION}

The effect of resistance exercise conditioning program on body mass and estimated percentage body fat

Body mass was significantly greater in males compared with females both before and after the conditioning program. Percentage body fat was significantly higher in females compared with males both before and after conditioning. These data are normal for such a population.

The resistance exercise conditioning program had no effect on body mass and percentage body fat in either males or females. This is in agreement with Wilmore et al ${ }^{13}$ who found no significant changes in body mass and percentage body fat in either sex after a 10-week circuit weight-training program encompassing 3 circuits of 10 stations, 3 days per week. Data also concur with the findings of Kokkinos et al ${ }^{14}$ who compared low and high-repetition resistance exercise training programs and found no significant changes in body mass and percentage body fat after 10 weeks of training. It should be noted, however, that Wilmore et al ${ }^{13}$ and Kokkinos et al ${ }^{14}$ found an increase in lean body mass in response to resistance exercise training. Other investigators ${ }^{15}$ found a decrease in percentage body fat in males and females after 16 weeks of weight-training. The fact that the decrease in the percentage body fat was not statistically significant in the present study may probably be linked with the duration of the training program which was only 8 weeks. Pollock ${ }^{16}$ stated that programs of 8 to 10 weeks duration generally result in less changes in body composition parameters compared with longer duration. However, this is not always the case. For example, Hurley et al ${ }^{17}$ failed to demonstrate a significant changes in body composition after 16-week high-intensity resistive training on 11 healthy untrained males.

The present work also showed that body mass and percentage body fat did not change significantly between placebo and ginseng groups in response to resistance exercise training. No data seem to be available in the literature regarding the effect of ginseng supplementation on body composition in humans. Animal studies showed that ginseng supplementation increased the body weight of mice, ${ }^{18}$ but it was not clear whether this increase was due to an increase in lean body mass, fatty tissue or water retention. High doses of ginseng which have been used in these animal studies would not be considered safe in humans. Thus it is suggested that ginseng ingested in a dose com- 
patible with safety $\left(600 \mathrm{mg} \cdot \mathrm{day}^{-1}\right)$ had no effect on body composition.

\section{The effect of resistance exercise conditioning pro- gram on strength development}

Muscular strength, as measured in total exercise volume lifted, was significantly greater in males compared with females before and after the conditioning program. These data are in agreement with the results of previous research ${ }^{19}$ which showed that total body strength in females was $63.5 \%$ compared with males. Females' upper and lower body strength were $55.8 \%$ and $71.9 \%$, respectively, compared with muscular strength in males. It appears that when the effects of additional habitual physical activities are taken into account, the strength gain in response to resistance exercise training in males and females are directly related to lean body mass. Falkel et al ${ }^{8}$ found that the arm and leg strengths of males and females as measured on an isokinetic dynamometer were equal when expressed relative to lean body mass. One of the factors responsible for the difference in lean body mass between males and females is likely be due to a greater level of androgens in males. ${ }^{20}$

Males and females exhibited $18.1 \%$ and $17.9 \%$ in strength gain following resistance exercise training. These data are in agreement with the findings of Wilmore et $a{ }^{13}$ who reported similar strength gains after weight training in men and women. The absence of significant changes in body composition and the increase in strength performance in the present study could be due to neural mechanisms. This is based on the evidence that strength development in studies of 8-20 weeks duration is mainly associated with neural adaptations such as improved co-ordination and learning and increased activation of the muscles acting as prime movers. ${ }^{21}$ Wilmore and Costill ${ }^{22}$ revealed that motor unit recruitment is a key factor in strength gains. It has been generally accepted that whether the muscle fibers contract or relax depends on the summation of the many impulses received by that motor unit at any one time. Strength gains may result from recruitment of additional motor units to act synchronously, facilitating contraction and increasing the muscle's ability to generate force. ${ }^{22}$

Resistance exercise training induced similar increases in muscular strength in placebo and ginseng groups (14\% in the placebo group and $20 \%$ in the ginseng group). This finding suggests that there was no additional ergogenic effect of ginseng $\left(600 \mathrm{mg}\right.$.day $\left.{ }^{1}\right)$ on the development of muscular strength in response to resis- tance exercise training. Most of the previous studies employed endurance exercise to assess the ergogenic effects of ginseng supplementation on physical performance. These studied showed that ginseng ingestion improves maximal aerobic power as assessed by $\mathrm{VO}_{2} \max .^{23,24}$ Similarly, Pieralisi et $\mathrm{al}^{25}$ demonstrated that 6 weeks supplementation of ginseng resulted in an increase in total work load during treadmill run. McNaughton et $\mathrm{al}^{5}$ examined the effects of two different types of ginseng supplementation (Russian and Chinese) on strength development. Pectoral and quadriceps strength measures were significantly greater only in the group who had ingested the Chinese ginseng compared with controls. This contrasts with the findings of the present study and could be attributed to the ginseng dose administered $(600 \mathrm{mg}$ in the present study vs $1000 \mathrm{mg}$ in the study of McNaughton et $\mathrm{al}^{5}$ ).

Animal studies ${ }^{3,26}$ also demonstrated an increase in muscular strength with ginseng supplementation. However, the doses used in the latter studies (15-150 mg. $\mathrm{kg}^{-1}$ body weight.day ${ }^{-1}$ ) were substantially higher than the dose administered in the present investigation. It is possible that the administration of a higher dose of ginseng enhances muscular strength. Because it has long been recognized that higher doses of ginseng ingestion lead to side effects ${ }^{2 \gamma}$, in the present study a dose $(600 \mathrm{mg})$ compatible with safety was administered.

\section{CONCLUSION}

It was established that the program of the resistance exercise training twice a week for eight weeks had no effect on body mass and percentage body fat in either males or females and between the placebo and ginseng groups. No significant change in body composition in the present study could be related to the intensity, frequency, or duration of the training program.

Resistance exercise training twice a week for eight weeks induced a significant increase in muscular strength, expressed as total exercise volume lifted, in males and females with males generating significantly greater weight volume than females before and after the conditioning program. Likewise, a statistically significant increase in total exercise volume was found as a result of the resistance exercise training, with no difference being observed between the placebo and the ginseng group post-training. The absence of significant changes in body composition and the increase in strength performance in the present study could be due to neural mechanisms. 


\section{Acknowledgments}

Many thanks to Dr. Mahmoud El-Sayed, FACSM and Prof. Dr. Thomas Reilly, Center for Sport and Exercise Sciences, School of Human Sciences, Liverpool John Moores University, England for their supports and advises throughout the course of the work. My appreciation is also extended to all the participants of this study without whom the research would not have been possible.

\section{REFERENCES}

1. Goldstein B. Ginseng: its history, dispersion, and folk tradition. Am J Chinese Med 1975; 3: 223-34.

2. Cartwright L. Ginseng in pharmacies. Australian J Pharm 1979;3:346-9.

3. Popov IM, Goldwald WJ. A review of the properties and clinical effects of ginseng. Am J Chinese Med 1973;1:26370.

4. Kirchdorfer AM. Clinical trials with the standardized ginsenoside concentrate G115. In Chang HM, Yeung HW, Tso W. Koo A, editors. Advances in Chinese Medicinal Materials Research. Singapore, World Scientific Publication Company; 1985. p. 29-42.

5. McNaughton L, Egan D, Caelli G. A comparison of Chinese and Russian ginseng as ergogenic aids to improve various facets of physical fitness. Int Clin Nutr Review 1989;9:32-6.

6. Fleck SJ, Kraemer WJ. Designing Resistance Training Programs. Champaign, IL.: Human Kinetics; 1988.

7. Getmann LR, Ayres JJ, Pollock ML. The effect of circuit weight training on strength, cardiorespiratory function, and body composition of adult men. Med Sci Sports Exerc 1978;10:171-6.

8. Falkel JE, Sawka MN, Levine L, Pandolf KB. Upper to lower body muscular strength and endurance ratios for female and male. Ergonomics 1985;28: 1661-70.

9. Dudley GA. Metabolic consequences of resistive-type exercise. Med Sci Sports Exerc 1988;20 Suppl 1:158-61.

10. Enoka RM. Muscle strength and its development: New perspectives. Sports Med 1988; 6: 146-68.

11. Durnin JG, Womersley J. Body fat assessed from total body density and its estimation from skinfold thickness; measurements on 481 men and women aged 16 to 72 years. Br J Nutr $1974 ; 21: 77-97$
12. Wathen D. Training volume. In : Baechle TR, editor. Essentials of strength training and conditioning. Campaign IL, Human Kinetics; 1994.p. 447-50.

13. Wilmore JH, Parr RB, Girandola RN, Ward P, Vodak, PA, Barstow TJ, et al. Physiological alterations consequent to circuit weight training. Med Sci Sports 1978;10:79-84.

14. Kokkinos PF, Hurley BF, Vaccaro P, Patterson JC, Gardner $\mathrm{LB}$, Ostrove SM et al. Effects of low- and high-repetition resistive training on lipoprotein-lipid profiles. Med Sci Sports Exerc 1988; 20:50-4

15. Goldberg L, Elliot DL, Schultz RW, Kloster FE. Changes in lipid and lipoprotein level after weight training. JAMA $1984 ; 252: 504-6$

16. Pollock ML. The quantification ef endurance training programs. In Wilmore JH, editor. Exercise and Sport Sciences Review. New York Academic Press; 1973. p.155-8.

17. Hurley BF, Hagberg M, Goldberg AP, Seals DR, Ehsani AA, Brennan RE et al. Resistive training can reduced coronary risk factors without altering $\mathrm{VO}_{2} \mathrm{max}$ or percent body fat. Med Sci Sports Exerc 1988; 20:150-4.

18. Kim HS. The effect of ginseng administration on body mass in rats. Am J Chinese Med 1970; 7:23-9.

19. Laubach LL. Comparative muscular strength of men and women : A review of the literature. Aviation, Space and Envir Med 1976;47:534-42.

20. Kraemer WJ, Noble BJ, Clark MJ and Culver BW. Physiologic responses to heavy-resistance exercise with very short resting periods. Int J Sports Med 1987;8:247-52.

21. Sale DG. Neuroadaptation to resistance training. Med Sci Sports Exerc 1988;20: Suppl 1:135-45.

22. Wilmore JH, Costill DL. Physiology of sport and exercise. Champaign IL.: Human Kinetics; 1994.

23. Forgo I, Kirchdorfer AM. The effect of different ginsenoside concentrations on physical work capacity. Notabene Med 1982;12:721-7.

24. Forgo I, Schimert G. The duration of effect of the standardized ginseng extract G115 in healthy competitive athletes. Notabene Med 1985;15:636-40.

25. Pierallisi G, Ripari P, Vecchiet L. Effects of standardized ginseng extract combined with dimethylaminoethanol bitartrate, vitamins, minerals, and trace elements on physical performance during exercise. Clinical Therapy 1991;13:373-82.

26. Filaretov AA, Bogdanova TS, Podvigina TT, Bodganova AI. Role of pituitary-adrenocortical system in body adaptation abilities. Exp Clin Endocrinology 1988;92:129-36.

27. Siegel RK. Ginseng and high blood pressure. JAMA 1979;243:32. 